\title{
Effects of vertical distribution of soil inorganic nitrogen on root growth and subsequent nitrogen uptake by field vegetable crops
}

\author{
H. L. Kristensen \& K. Thorup-Kristensen \\ Department of Horticulture, University of Aarhus, Kirstinebjergvej 10, DK-5792 Aarslev, Denmark
}

\begin{abstract}
Information is needed about root growth and $\mathrm{N}$ uptake of crops under different soil conditions to increase nitrogen use efficiency in horticultural production. The purpose of this study was to investigate if differences in vertical distribution of soil nitrogen $\left(\mathrm{N}_{\text {inorg }}\right)$ affected root growth and $\mathrm{N}$ uptake of a variety of horticultural crops. Two field experiments were performed each over 2 years with shallow or deep placement of soil $\mathrm{N}_{\text {inorg }}$ obtained by management of cover crops. Vegetable crops of leek, potato, Chinese cabbage, beetroot, summer squash and white cabbage reached root depths of $0.5,0.7$, 1.3, 1.9, 1.9 and more than $2.4 \mathrm{~m}$, respectively, at harvest, and showed rates of root depth penetration from 0.2 to $1.5 \mathrm{~mm}$ day $^{-1}{ }^{\circ} \mathrm{C}^{-1}$. Shallow placement of soil $\mathrm{N}_{\text {inorg }}$ resulted in greater $\mathrm{N}$ uptake in the shallow-rooted leek and potato. Deep placement of soil $\mathrm{N}_{\text {inorg }}$ resulted in greater rates of root depth penetration in the deep-rooted Chinese cabbage, summer squash and white cabbage, which increased their depth by $0.2-0.4 \mathrm{~m}$. The root frequency was decreased in shallow soil layers (white cabbage) and increased in deep soil layers (Chinese cabbage, summer squash and white cabbage). The influence of vertical distribution of soil $\mathrm{N}_{\text {inorg }}$ on root distribution and capacity for depletion of soil $\mathrm{N}_{\text {inorg }}$ was much less than the effect of inherent differences between species. Thus, knowledge about differences in root growth between species should be used when designing crop rotations with high $\mathrm{N}$ use efficiency.
\end{abstract}

Keywords: Deep roots, horticulture, nitrate, minirhizotron, root density, soil nitrogen, subsoil

\section{Introduction}

For many years, it has been a major concern to increase the $\mathrm{N}$ use efficiency in horticultural systems as growing of vegetables often leaves much $\mathrm{N}$ in the soil after harvest. This $\mathrm{N}$ may leach to deeper soil layers in the form of nitrate, and eutrophy the water environment (Di \& Cameron, 2002). This concern is gaining new attention in, e.g. the European Union with the Water Framework Directive (Directive 2000/60/EC), and further demands on horticultural production with the aim to reduce nitrate leaching are expected. Nitrate leaching may be reduced by use of knowledge about root depth of crops (Kristensen and Thorup-Kristensen, 2004a,b; Thorup-Kristensen, 2006a). Deep-rooted crops (>1-m depth) should be grown where much nitrate is available in deep soil layers to increase uptake and

Correspondence: H. L. Kristensen.

E-mail: hanne.kristensen@agrsci.dk

Received October 2006; accepted after revision June 2007 recycling of $\mathrm{N}$ from depth. Thus, root depth should where feasible match the depth distribution of soil $\mathrm{N}_{\text {inorg }}$ in the design of crop rotations (Thorup-Kristensen, 2006a). On the other hand, it is well known that $\mathrm{N}$ distribution may affect root growth locally in the root system, with consequences for $\mathrm{N}$ uptake and plant performance (e.g. Forde \& Lorenzo, 2001). To enable design of crop rotations with $\mathrm{N}$ uptake from deep soil layers it is therefore important to know how $\mathrm{N}$ distribution affects root growth and $\mathrm{N}$ uptake of crops at field scale.

Knowledge has been gained in laboratory studies about effects of $\mathrm{N}$ enrichment in patches on root proliferation, morphology and N uptake (e.g. Drew \& Saker, 1975; Hodge, 2004). In enriched patches, root density was found to be higher, and this may be important for inter-species competition on soil N. However, field studies of effects of $\mathrm{N}$ distribution on crop root growth are scarce (Schenk et al., 1991; Thorup-Kristensen, 1993; Gao et al., 1998; Christiansen et al., 2006). This is contrasted by numerous studies of 
effects of $\mathrm{N}$ fertilization on root growth. A review of the studies showed, that restricted $\mathrm{N}$ supply or deep placement of $\mathrm{N}$ increased density of roots in upper parts of the rooting zone, or in the entire root zone of some crops compared with a large $\mathrm{N}$ supply or shallow placement (Schenk et al., 1991; Thorup-Kristensen, 1993; Thorup-Kristensen \& Van den Boogaard, 1999). This indicates that moderate $\mathrm{N}$ deficiency in crops may result in allocation of resources to the roots that increase the exploration of the soil for nutrients. Other crops showed no effect of $\mathrm{N}$ fertilization or distribution on root density and/or root depth (Schenk et al., 1991; ThorupKristensen \& Van den Boogaard, 1999; Rather et al., 2000; Vamerali et al., 2003; Christiansen et al., 2006). This was contrasted by many studies showing that application of $\mathrm{N}$ or organic matter increased root density in surface soil layers (Opena \& Porter, 1999; Sharifi et al., 2005) or at depth (Vamerali et al., 2003), and that final root depth was increased (Barraclough et al., 1989). However, in these fertilizer studies, interpretation of the effect of soil $\mathrm{N}_{\text {inorg }}$ distribution on root growth cannot be distinguished from the effect of increased availability of nutrients on overall crop performance. It was typical in these studies for the effects on root growth to be connected to large differences in biomass production (e.g. Vamerali et al., 2003). Further due to limited sampling depth, effects of $\mathrm{N}$ fertilizer or distribution on maximum root depth and distribution are seldom reported, even for shallow-rooted crops (e.g. Sharifi et al., 2005). Against this background, the question arises of how differences in distribution of soil $\mathrm{N}_{\text {inorg }}$ affects root density and root depth of crops under conditions where crop $\mathrm{N}$ requirements are met, but not greatly exceeded; i.e. under conditions of horticultural production that are efficient in $\mathrm{N}$ use. Does deep placement of $\mathrm{N}_{\text {inorg }}$ stimulate roots to grow deeper and denser, or is $\mathrm{N}$ distribution of minor importance for overall development of root systems?

The distribution of $\mathrm{N}_{\text {inorg }}$ in soil is affected by a number of factors; one of them is the management of cover crops (green manures and catch crops). Cover crops take up $\mathrm{N}_{\text {inorg }}$ within their rooting zone. This $\mathrm{N}$ is later made available for crop uptake or leaching when incorporated in the topsoil (Thorup-Kristensen et al., 2003; ThorupKristensen, 2006b). The time of incorporation of cover crops relative to the periods of high leaching intensity is a major factor that determines the vertical distribution of soil $\mathrm{N}_{\text {inorg }}$ for the following crop. Thus, different distributions of soil $\mathrm{N}_{\text {inorg }}$ may be obtained by varying the management of cover crops.

Horticultural production is often characterized by the growing of a large diversity of crops. To design horticultural crop rotations with increased $\mathrm{N}$ use efficiency, we need more knowledge about root growth in a wider range of commercial crops. The objectives of this study were to investigate: (a) root distribution and depth in a variety of well-grown vegetable crops; and (b) the effects of deep placement of soil
$\mathrm{N}_{\text {inorg }}$ on root growth and $\mathrm{N}$ uptake of the crops compared with shallow placement.

\section{Materials and methods}

\section{Field site and experimental design}

Two field experiments were performed with different management of cover crops to obtain different vertical distributions of soil $\mathrm{N}_{\text {inorg. }}$. The cover crops were followed by growing a variety of vegetable crops at the Research Centre at Aarslev $\left(10^{\circ} 27^{\prime} \mathrm{E}, 55^{\circ} 18^{\prime} \mathrm{N}\right)$ in Denmark. In experiment A, three vegetable crops were grown after two catch crops or bare soil. In experiment B, three vegetable crops were grown after green manure which had been incorporated in the soil in the previous autumn or spring. The soil was a sandy loam (Typic Agrudalf) with the 0 - to $0.5-\mathrm{m}$ soil layer containing $1.1 \% \mathrm{C}, 13 \%$ clay, $15 \%$ silt and $70 \%$ sand; the $0.5-$ to $1-\mathrm{m}$ layer containing $0.3 \% \mathrm{C}, 19 \%$ clay, $13 \%$ silt and $68 \%$ sand and the 1- to $2.5-\mathrm{m}$ layer containing $0.2 \% \mathrm{C}, 18 \%$ clay, $14 \%$ silt and $68 \%$ sand. The $\mathrm{pH}_{\mathrm{CaCl}_{2}}$ was $6.3,5.4$ and 6.8 in the 0 - to $0.5-, 0.5$ - to 1 - and 1- to 2.5-m layers, respectively. Average annual precipitation $(624 \mathrm{~mm})$ and air temperature $\left(7.8^{\circ} \mathrm{C}\right)$ were recorded at a meteorological station at the research centre. In both experiments, the vegetables were irrigated when precipitation deficits exceeded $30 \mathrm{~mm}$. The field had been managed according to organic farming practice since 1996.

In experiment $A, 16$ plots each of $7.5 \times 10 \mathrm{~m}^{2}$ were arranged in a randomized complete block design with two replicates. Six plots were left bare, six plots were sown with the catch crop Italian ryegrass (Lolium multiflorum Lam. 'Bofur') and four plots with the catch crop fodder radish (Raphanus sativus L. var. oleiformis Pers.) on 8 August 2000 and 31 July 2001. The catch crops were grown after incorporation of a mixture of clover and grass by ploughing. The following spring, the catch crops were incorporated by ploughing on 28 March 2001 and 2 April 2002. Twelveweek-old transplants of leek (Allium porrum 'Parton') were planted after bare soil, ryegrass and radish on 30 May 2001 and 29 May 2002. Beetroot (Beta vulgaris L. ssp. vulgaris var. conditiva Alef. 'Forona') was sown after bare soil and ryegrass on 24 May 2001 and 28 May 2002. Seven and 10week-old transplants of white cabbage (Brassica oleracea L. convar. capitata (L.) Alef. var. alba DC 'Impala') were planted on 10 May 2001 and 27 May 2002, respectively, after bare soil, ryegrass and radish. The distance between rows was $0.5 \mathrm{~m}$, and between plants $0.08 \mathrm{~m}$ for leek and $0.5 \mathrm{~m}$ for cabbage. Dried chicken manure at $2000 \mathrm{~kg} \mathrm{ha}^{-1}$ containing $100 \mathrm{~kg} \mathrm{~N} \mathrm{ha}^{-1}$, was applied to the vegetables on 7 June 2001 and 24 May 2002.

In experiment $\mathrm{B}$, a mixture of clover and grass was undersown in spring barley in spring. The mixture consisted of white clover (Trifolium repens L.), black medick (Medicago 
lupulina L.), birdsfoot trefoil (Lotus corniculatus L.), ryegrass (Lolium perenne L.), timothy (Phleum pratense L.) and meadow fescue (Festuca pratensis Huds.). The green manure was left growing after harvest of the barley in early August and ploughed in autumn (25 October 2001 and 15 November 2002) or spring (2 April 2002 and 19 March 2003). Three vegetables were planted after each green manure treatment in plots arranged in a randomized complete block design with three replicates making a total of 18 plots. An early variety of potato (Solanum tuberosum L. 'Ditta') was planted in $10 \times 3 \mathrm{~m}^{2}$ plots on 14 May 2002 and 8 May 2003 with $0.75 \mathrm{~m}$ between rows and $0.3 \mathrm{~m}$ between plants. Four-weekold transplants of Chinese cabbage (Brassica campestris L. ssp. pekinensis 'Kasumi') were planted in $10 \times 2.5 \mathrm{~m}^{2}$ plots on 14 May 2002 and 25 April 2003 with a distance of $0.5 \times 0.5 \mathrm{~m}$, and covered by polypropylene fleece to prevent insect damage. Three- and four-week-old transplants of summer squash (Cucurbita pepo Duch. 'Ambassador') were planted in $10 \times 4.5 \mathrm{~m}^{2}$ plots on 22 May 2002 and 28 May 2003, respectively, with $1 \mathrm{~m}$ between rows and $0.5 \mathrm{~m}$ between plants.

\section{Root measurements}

Root distribution was measured using minirhizotrons (Kristensen \& Thorup-Kristensen, 2004a) which were glass tubes of 1.5 or $3-\mathrm{m}$ length and $70-\mathrm{mm}$ outer diameter. These were inserted along plant rows at an angle of $30^{\circ}$ from the vertical at the start of growth. The tubes reached a depth of approximately 1.2 (leek 2001, 2002; potato 2002, 2003 and summer squash 2002) or $2.42 \mathrm{~m}$ (all others) into the soil. In experiment $A$, three minirhizotrons were installed at $0.1-\mathrm{m}$ distance from the rows in each plot. In experiment B, two minirhizotrons were installed, one in and one between the rows, in each plot. This resulted in a total of six replicate minirhizotrons in each cover crop-crop combination in both experiments. Along each minirhizotron, two replicate counting grids (rows of $40 \times 40 \mathrm{~mm}^{2}$ ) were painted. A mini-video camera was used to record the roots at the minirhizotron surface. From those recordings, root depth, root intensity and root frequency were obtained. Root depth was measured as the deepest root observed in each of the two counting grids. Root intensity, as an expression of root density, was calculated from the total number of roots crossing the lines in each $40 \times 40 \mathrm{~mm}^{2}$ as root intersections per metre grid line (intersections $\mathrm{m}^{-1}$ ). The root frequency, which expresses the ability for depletion of soil $\mathrm{N}_{\text {inorg }}$, was obtained by observing presence/absence of roots crossing the lines in each $40 \times 40 \mathrm{~mm}^{2}$. Then the percentage of $40 \times 40 \mathrm{~mm}^{2}$ with roots present was calculated for each $0.5-\mathrm{m}$ soil layer (Thorup-Kristensen, 2001). A root depth penetration rate $\left(\mathrm{mm}\right.$ day $^{-1}{ }^{\circ} \mathrm{C}^{-1}$ ) was calculated as the slope of the regression line of the average root depth versus accumulated daily average temperature from planting or sowing (base temperature of $0^{\circ} \mathrm{C}$ ).

\section{Plant and soil sampling and analysis}

Above ground plant biomass was sampled from subplots of $2.25-4.5 \mathrm{~m}^{2}$ at harvest in both experiments: leek and white cabbage on 29 October 2001 and 1 October 2002, beetroot including storage root on 24 October 2001 and 1 October 2002, potato including tubers on 22 July 2002 and 17 July 2003, Chinese cabbage on 22 July 2002 and 30 June 2003, and summer squash $(>0.25 \mathrm{~kg})$ every week until mid-September including the above ground biomass on 22 July 2002 and 10 September 2003. In both experiments, the samples were kept at $1{ }^{\circ} \mathrm{C}$, chopped, and dried at $80{ }^{\circ} \mathrm{C}$ for $20 \mathrm{~h}$. Nitrogen content was determined by a combustion method (thermal conductivity detector, vario-MAX CNS). Soil was sampled for an analysis of $\mathrm{N}_{\text {inorg }}$ content to 2.5- and 1.5-m depth in experiments $\mathrm{A}$ and $\mathrm{B}$, respectively. In both experiments, nine samples were taken with a soil auger in each plot. The samples were divided into depth intervals of $0.5 \mathrm{~m}$, and pooled to one composite sample for each interval and plot. The composite samples were mixed and a subsample was immediately frozen at $-18{ }^{\circ} \mathrm{C}$ for later analyses. The frozen soil samples were thawed and $100 \mathrm{~g}$ of soil was immediately weighed and extracted in $1 \mathrm{~m} \mathrm{KCl}$ for $1 \mathrm{~h}$ (soil:solution ratio 1:2). The soil extract was filtered and analysed for $\mathrm{NH}_{4}{ }^{+}$and $\mathrm{NO}_{3}{ }^{-}$content by flow injection (Lachat 8000 ). Soil $\mathrm{N}_{\text {inorg }}$ content was calculated on an area basis by use of the average volumetric soil density determined for each depth interval.

\section{Statistical analysis}

Statistical significance of differences in root distribution, plant and soil pools between crops and treatments was tested by analysis of variance ( $F$ test). Multiple comparisons were based on values of the least significant difference (LSD) derived from analyses of variance (Proc GLM, SAS Institute Inc., Cary, NC, USA). Root frequencies were transformed prior to analyses by the logit transformation (logitp $=\log [p /(1-p)]$ ) to obtain homogeneity of variance. Relationships between root depth and accumulated daily temperature were investigated by simple linear regression modelling and test of homogeneity of slopes. In assessing differences between results, tests with $P<0.05$ were considered statistically significant. Annual differences were small relative to differences between crops and treatments, and results are therefore presented as averages over the two experimental years.

\section{Results}

In both experiments, the management of cover crops affected the soil $\mathrm{N}_{\text {inorg }}$ distribution in spring, and the management of cover crop followed by the growing of 
crops affected the soil $\mathrm{N}_{\text {inorg }}$ at harvest (Figures 1 and 2). In experiment $\mathrm{A}$ in spring, significant differences were seen in the $0-0.5-\mathrm{m}$ soil layer between bare soil, ryegrass and fodder radish; and in the $0.5-$ to $2.5-\mathrm{m}$ soil layer between bare soil and rye grass/fodder radish (Figure 1a). No differences were found in the total amount of soil $\mathrm{N}_{\text {inorg }}$ in the 0 - to 2.5-m soil layer between cover crop managements in spring (180 $\left.\mathrm{kg} \mathrm{N} \mathrm{ha}^{-1}\right)$. At harvest of the vegetable crops in experiment $\mathrm{A}$, differences of up to $134 \mathrm{~kg} \mathrm{~N} \mathrm{ha}^{-1}$ were recorded between the total amounts of $\mathrm{N}_{\text {inorg }}$ left on average below crops (Table 1). Differences for the same species were up to $73 \mathrm{~kg} \mathrm{~N} \mathrm{ha}^{-1}$ depending on cover crop management. The differences were found mainly in the soil layers below 0.5-m depth (Figure 1b). The average $\mathrm{N}$ content in the above ground biomass differed by up to $107 \mathrm{~kg} \mathrm{ha}^{-1}$ among crops in experiment A (Table 1). A difference of $38 \mathrm{~kg} \mathrm{ha}^{-1}$ was found in the $\mathrm{N}$ content of leek depending on cover crop management. The yields of saleable product of leek, beetroot and white cabbage amounted to 34, 49 and $63 \mathrm{t}$ fresh weight $\mathrm{ha}^{-1}$, respectively.

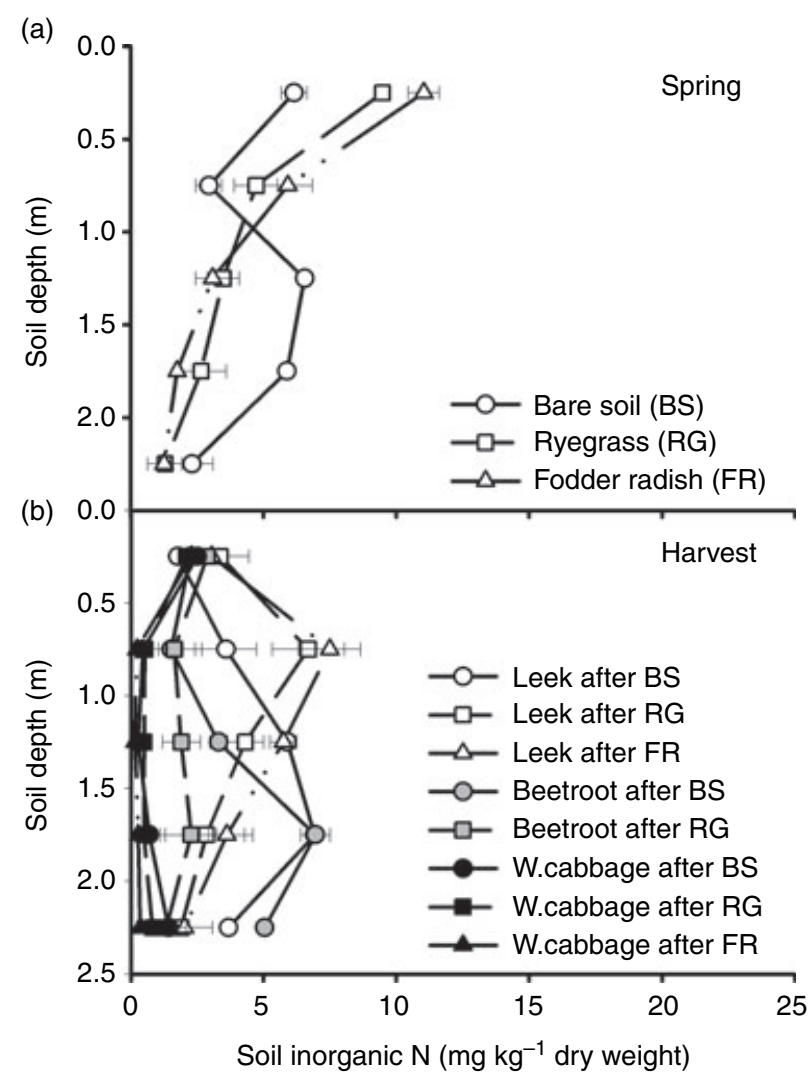

Figure 1 Distribution of soil inorganic $\mathrm{N}$ in soil layers in experiment $A$, (a) in spring after incorporation of a cover crop of bare soil (BS), ryegrass (RG) or fodder radish (FR); and (b) at harvest of a crop of leek, beetroot or white cabbage grown after the cover crops. Bars indicate standard errors for averages over 2 years $(n=2)$.
In experiment $\mathrm{A}$, root depth differed at harvest between species by up to $1.9 \mathrm{~m}$ (Table 2, Figure 3), and the rate of root depth penetration (slope of line from linear regression) differed between species by up to $1.22 \mathrm{~mm} \mathrm{day}{ }^{-1}{ }^{\circ} \mathrm{C}^{-1}$. Within species, differences were found for white cabbage of $0.14 \mathrm{~mm} \mathrm{day}^{-1}{ }^{\circ} \mathrm{C}^{-1}$ when grown after bare soil instead of after cover crops. Root intensity of the vegetable crops in experiment A differed strongly among species in the 0.5 - to 2-m layer (Figure 4). Differences within species were found for white cabbage with higher intensities in the 0.5 - to $1-\mathrm{m}$ layer; and lower intensities in the 1.5- to 2-m layer when grown after a cover crop, compared with bare soil. The root frequency was very low for all three crops in June in experiment A (Figure 5). In July, frequencies were still below 30\% and few differences between species were found. In August, frequencies were much larger and there were clear differences between species. Root frequencies were much larger in September, especially in the 0 - to 0.5 - $\mathrm{m}$ layer for leek and in the 0.5 - to 2-m layer for beetroot and white cabbage. In October, differences between species were still pronounced but only in layers below $0.5-\mathrm{m}$ depth. At this time the root frequency reached the maximum value for leek in the 0 - to 0.5-m layer, and frequencies of beetroot and white cabbage had increased in the 1- to 2.4-m layer. Differences within species were seen for beetroot in the 0 - to $0.25-\mathrm{m}$ layer in October 2002. For white cabbage, root frequency was greater in the 0.5 - to $0.75-\mathrm{m}$ layer when cabbage was grown after fodder radish instead of after ryegrass/bare soil (August 2001) or ryegrass (September 2001). In the deeper soil layers, frequencies were the greatest when white cabbage was grown after bare soil compared with after fodder radish in the 1.25to 1.5-m layer (August 2002) and with fodder radish/ryegrass in the 1.5- to 2.4-m layer (October 2001).

In experiment $\mathrm{B}$ in spring, the concentrations of soil $\mathrm{N}_{\text {inorg }}$ in the 0.5 - to $1.5-\mathrm{m}$ layer was larger after incorporation of cover crops in the autumn compared with after incorporation in the spring (Figure 2a). No differences were found in the total amount of soil $\mathrm{N}_{\text {inorg }}$ in the 0 - to $1.5-\mathrm{m}$ soil layer between cover crop managements in spring $\left(167 \mathrm{~kg} \mathrm{~N} \mathrm{ha}^{-1}\right)$. At harvest of the vegetable crops in experiment $\mathrm{B}$, differences of up to $38 \mathrm{~kg} \mathrm{~N} \mathrm{ha}^{-1}$, on average, were recorded between total amounts of soil $\mathrm{N}_{\text {inorg }}$ remaining at harvest (Table 1). Within species, differences were up to $20 \mathrm{~kg} \mathrm{~N} \mathrm{ha}^{-1}$. The concentrations were largest in the soil layers below potato (Figure 2b). The average $\mathrm{N}$ content in the above ground biomass differed by up to $106 \mathrm{~kg} \mathrm{ha}^{-1}$ between species in experiment B (Table 1). Differences within species were found for $\mathrm{N}$ content in potato and summer squash of 28 and $32 \mathrm{~kg} \mathrm{ha}^{-1}$, respectively. The yields of saleable product of potato, Chinese cabbage and summer squash amounted to 29, 55 and $157 \mathrm{t}$ fresh weight $\mathrm{ha}^{-1}$, respectively.

In experiment $\mathrm{B}$, root depth at harvest differed between species by up to $1.2 \mathrm{~m}$ (Table 2, Figure 3). Also the rate of root depth penetration differed between species by up to 
Table 1 Plant biomass, $\mathrm{N}$ content and soil inorganic $\mathrm{N}$ remaining at harvest in experiments $\mathrm{A}$ and $\mathrm{B}$

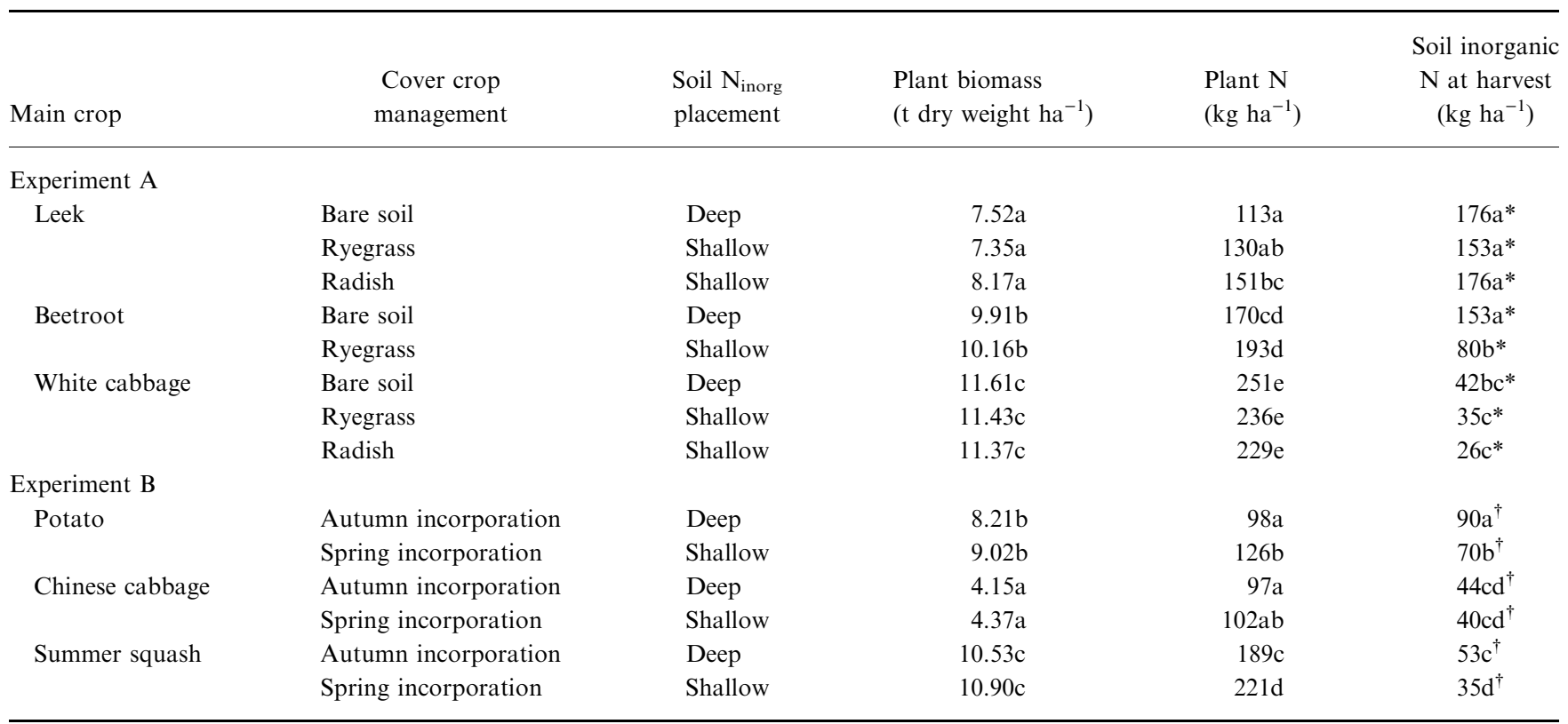

Numbers followed by different letters are significantly different within each experiment $(P=0.05)$. * Soil inorganic $\mathrm{N}$ measured in the 0 - to $2.5-\mathrm{m}$ soil layer in experiment A. ${ }^{\dagger}$ Soil inorganic $\mathrm{N}$ measured in the $0-$ to $1.5-\mathrm{m}$ soil layer in experiment $\mathrm{B}$.

Table 2 Root depth at harvest and outputs from a linear regression analysis of root depth $(Y)$ versus accumulated daily temperature above $0{ }^{\circ} \mathrm{C}$ $(X)$ in experiments A and B (Figure 2)

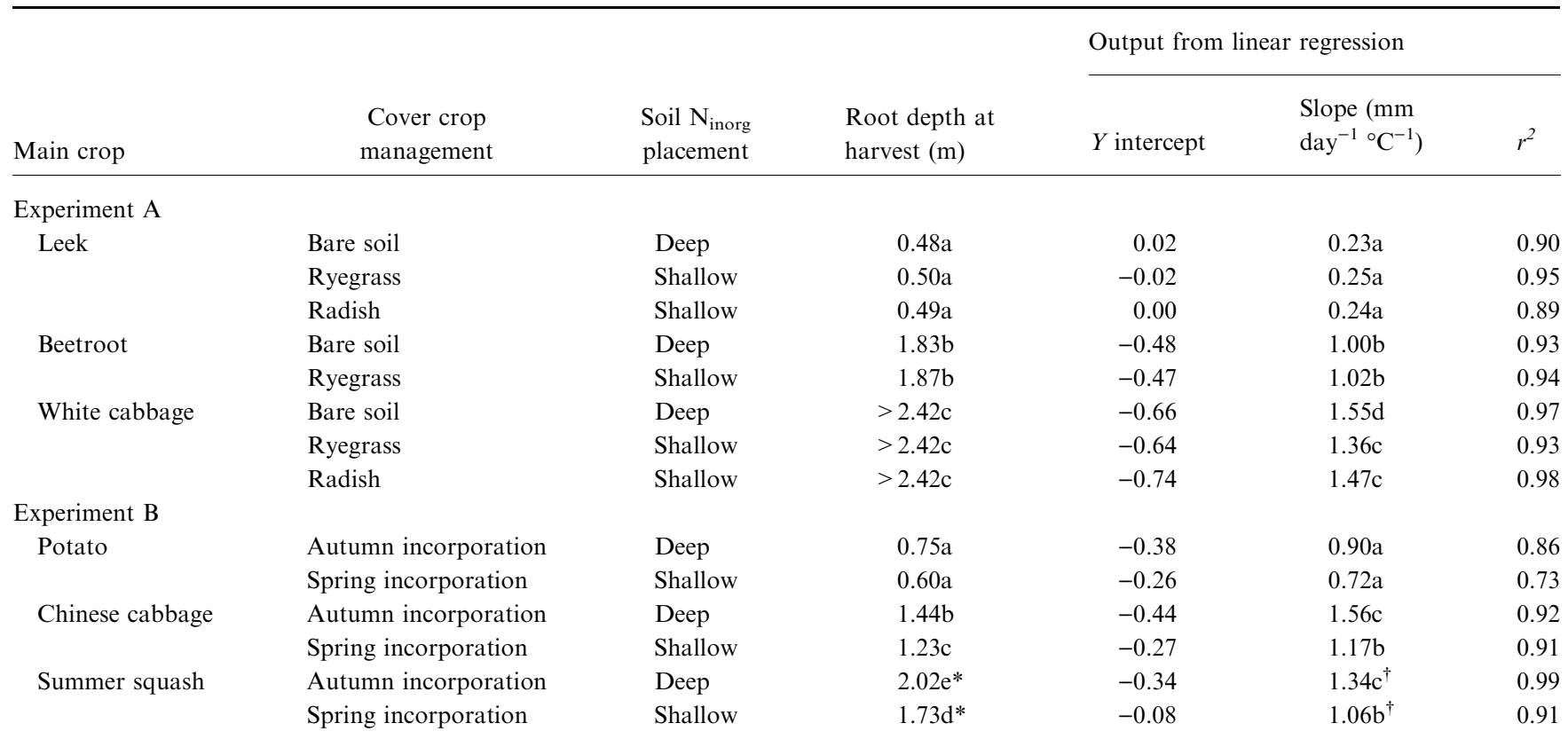

Numbers followed by different letters are significantly different within each experiment $(P=0.05)$. ${ }^{*}$ Root depth at harvest from 1 year only (2003). ${ }^{\dagger}$ The slopes presented for summer squash are based on the results from 2002 and 2003, but the difference between autumn and spring incorporation was statistically significant only in 2003 .

$0.56 \mathrm{~mm}$ day $^{-1}{ }^{\circ} \mathrm{C}^{-1}$ except between Chinese cabbage and summer squash. Differences within species were found for Chinese cabbage and summer squash of 0.21 and $0.29 \mathrm{~m}$ for root depth at harvest, and 0.39 and $0.28 \mathrm{~mm} \mathrm{day}^{-1}{ }^{\circ} \mathrm{C}^{-1}$, respectively, for root depth penetration rate. Root frequencies were generally greater in July in experiment B (Figure 6) than in July in experiment A (Figure 5). In experiment B, the frequencies were much greater in August than in July 


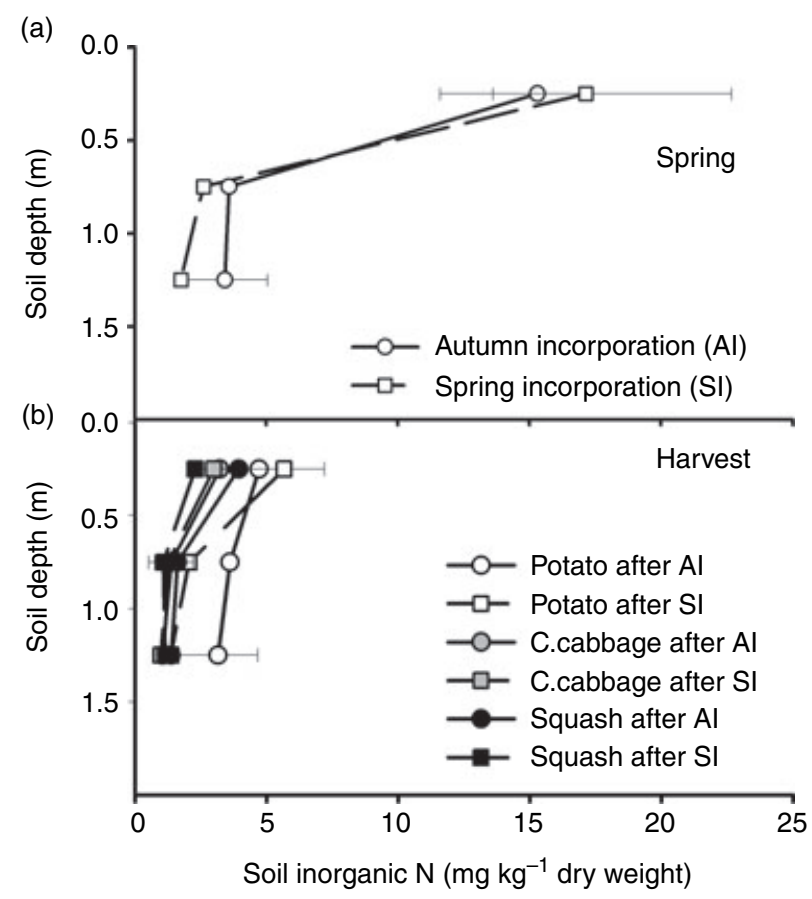

Figure 2 Distribution of soil inorganic $\mathrm{N}$ in soil layers in experiment $\mathrm{B}$, (a) in spring after incorporation of a cover crop in the previous autumn (AI) or spring (SI); and (b) at harvest of a crop of potato, Chinese cabbage or summer squash grown after the cover crops. Bars indicate standard errors for averages over 2 years $(n=2)$. Results for summer squash at harvest are from 2003 only.

especially for summer squash; and differences were found between potato and summer squash. Chinese cabbage had already been harvested at this time and therefore no data were recorded. In September, frequencies had increased strongly in the 1- to 2-m soil layer under summer squash compared with the previous measurement. Differences within species were found for Chinese cabbage in July in the 1- to 1.5-m layer and for summer squash in September 2003 in the 1.5- to 2-m layer.

Figure 7 shows the relationship between root frequency and the relative decrease in soil $\mathrm{N}_{\text {inorg }}$ from spring until harvest in each soil layer in both experiments. The results show that at root frequencies below 5\% there was no decrease in

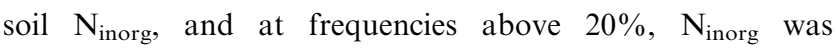
decreased by $40-100 \%$. Potato and beetroot were exceptions to this relationship with frequencies of between 20 and $40 \%$ resulting in decreases in Soil $\mathrm{N}_{\text {inorg }}$ of $20 \%$ or less (Figure 7 : potato layer 2, beetroot layer 4 ).

\section{Discussion}

\section{Root growth of species}

All crops continued root growth until harvest. Nevertheless, the vertical distribution of roots and the root depth varied

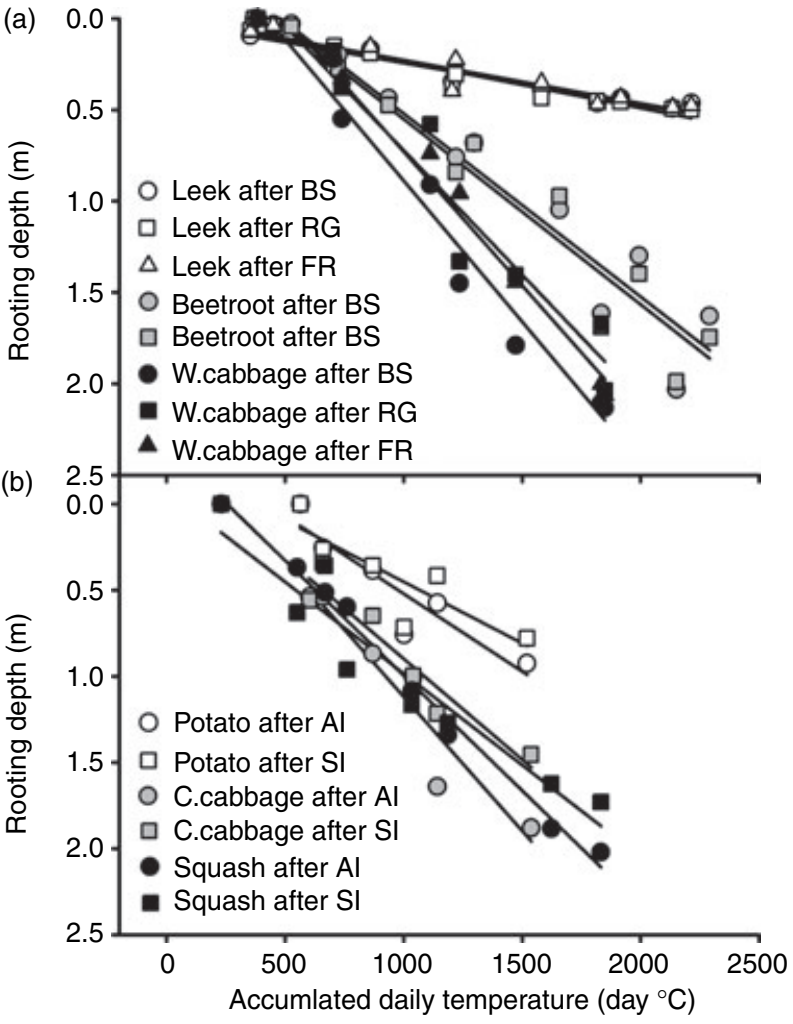

Figure 3 Rooting depth versus accumulated daily temperature above $0{ }^{\circ} \mathrm{C}$ from sowing or planting in experiment A: (a) leek, beetroot and white cabbage after a previous crop of bare soil (BS), ryegrass (RG) or fodder radish (FR); and in experiment B: (b) potato, Chinese cabbage and summer squash after cover crop incorporation in the previous autumn (AI) or spring (SI). Each symbol represents a point in time in 1 year. Outputs from a linear regression analysis are shown in Table 1.

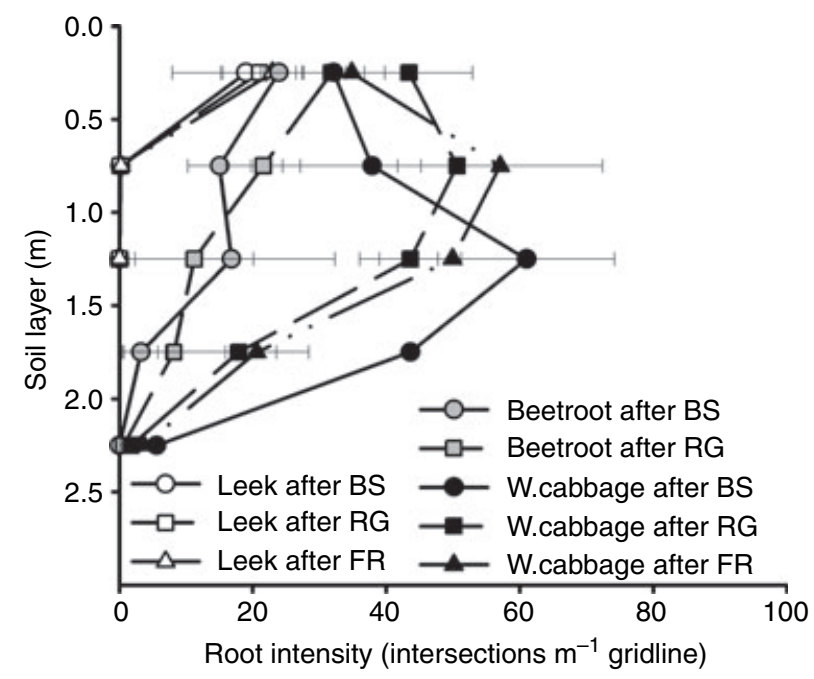

Figure 4 Root intensity at harvest in early September in experiment A of leek, beetroot and white cabbage after a previous crop of bare soil (BS), ryegrass (RG) or fodder radish (FR). Bars indicate standard errors for averages over 2 years $(n=2)$. 


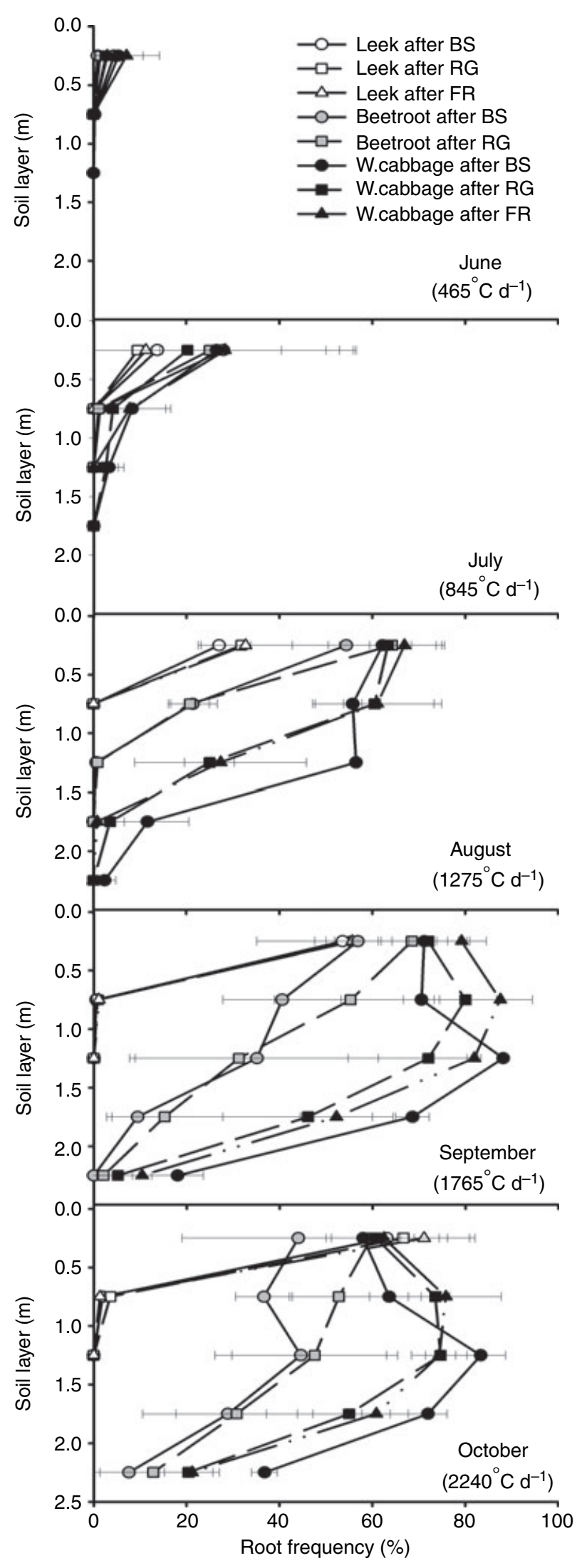

widely between species at harvest, and the rate of root depth penetration varied even more. For the deep-rooted crops, root growth from August until harvest was restricted entirely to below $0.75-\mathrm{m}$ depth as expressed by the root frequency. The results on root growth of Chinese cabbage are, to our knowledge, the first reported in the literature. The growth season was short, but due to the relatively high rate of depth penetration, Chinese cabbage still reached $1.3-\mathrm{m}$ depth at harvest in July. The rate of root depth penetration was comparable with that of another Brassica, white cabbage, in this and other studies (Kristensen \& Thorup-Kristensen, 2004b; Thorup-Kristensen, 2006b). The root frequency was relatively small in the surface soil layer, but comparable with frequencies obtained by white cabbage at a similar accumulated daily temperature. White cabbage was the deepest-rooted crop in the present study due to the long growing season and high rate of depth penetration. The results for beetroot confirmed a root depth of $1.7 \mathrm{~m}$ and a penetration rate of $0.9 \mathrm{~mm} \mathrm{day}{ }^{-1}{ }^{\circ} \mathrm{C}^{-1}$ found by Christiansen et al. (2006), whereas a higher rate of $1.6 \mathrm{~mm} \mathrm{day}{ }^{-1}{ }^{\circ} \mathrm{C}^{-1}$ was found under semi-field conditions in the Wageningen Rhizolab (Smit \& Groenwold, 2005). The closely related crop of sugar beet has been found to reach 2- to 3-m depth in the field (e.g. Weaver \& Bruner, 1927; Vamerali et al., 2003). The root intensity and frequency of beetroot were smaller than those of the deep-rooted Brassicas and summer squash in accordance with Smit \& Groenwold (2005). Summer squash roots grew very deep like other Cucurbits such as squash and pumpkin with root depths of $2 \mathrm{~m}$ (Weaver \& Bruner, 1927), and watermelon with at least $1.5 \mathrm{~m}$ (Xie et al., 2006). The root depth reached by summer squash was due to the long growing season in combination with a relatively high rate of root depth penetration. The shallow root depth found for leek confirmed previous field results of 0.4-0.6 m (Weaver \& Bruner, 1927; Smit et al., 1996). The rate of root depth penetration and proliferation were both slow, resulting in low root intensity at harvest as previously reported for leek in comparison with other vegetable crops (Smit et al., 1996; Smit \& Groenwold, 2005). Potato also was found to be shallow rooted as reported in the literature with depths of $0.6-1 \mathrm{~m}$ (Parker et al., 1989; Ruijter et al., 1996). The rate of root depth penetration was comparable with that of deeper rooted crops like beetroot and carrot (Thorup-Kristensen \& Van den Boogaard, 1999; Kristensen \& Thorup-Kristensen, 2004b). Therefore, the shallow root depth was due to the short growing season of this early variety, and to the leaf loss

Figure 5 Root frequency through the growing season in experiment A of leek, beetroot and white cabbage after a previous crop of bare soil (BS), ryegrass $(\mathrm{RG})$ or fodder radish (FR). The accumulated daily temperature above $0{ }^{\circ} \mathrm{C}$ from sowing or planting until the recording of root frequency is indicated in the lower right corner. Bars indicate standard errors for averages over 2 years $(n=2)$. 


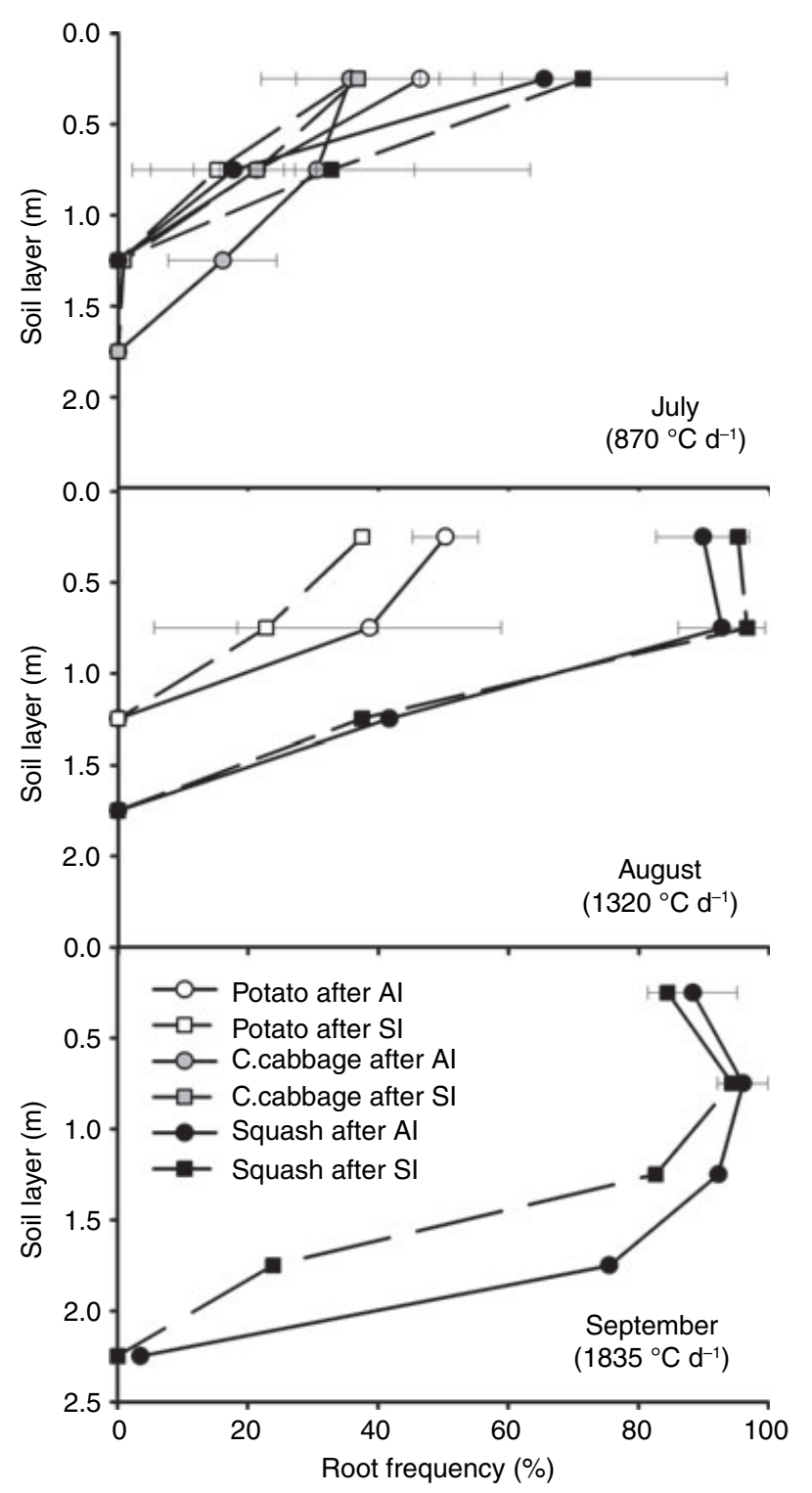

Figure 6 Root frequency through the growing season in experiment $B$ of potato, Chinese cabbage (at harvest only) and summer squash after previous incorporation of cover crop in autumn (AI) or spring (SI). The accumulated daily temperature above $0{ }^{\circ} \mathrm{C}$ from sowing or planting until recording of root frequency is indicated in the lower right corner. Results for summer squash below 1-m depth are from 2003 only. Bars indicate standard errors for averages over 2 years $(n=2)$.

caused by potato blight as commonly seen in organic farming. This was confirmed by Stalham \& Allen (2001) who found that a considerable range in root depths of 0.6-1.4 $\mathrm{m}$ was determined by differences in length of growing season and not in rate of root depth penetration in potato cultivars. The root distributions obtained for the six crop species were confirmed by the large reductions of $\mathrm{N}_{\text {inorg }}$ in the rooted soil layers indicating crop uptake of soil $\mathrm{N}_{\text {inorg }}$.

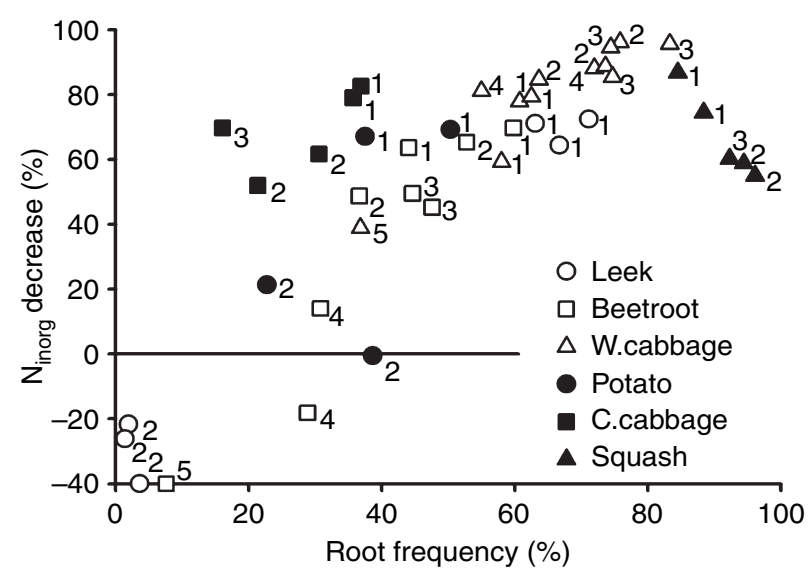

Figure 7 The decrease in soil $\mathrm{N}_{\text {inorg }}$ from spring until harvest as a percentage of soil $\mathrm{N}_{\text {inorg }}$ in spring versus root frequency at harvest for each $0.5-\mathrm{m}$ soil layer in experiment $\mathrm{A}$ of leek, beetroot and white cabbage; and in experiment $\mathrm{B}$ of potato, Chinese cabbage and summer squash. Each symbol represents an average over 2 years. The subscript number indicates the depth of the soil layer: $1=0-0.5 \mathrm{~m}$; $2=0.5-1 \mathrm{~m} ; 3=1-1.5 \mathrm{~m} ; 4=1.5-2 \mathrm{~m}$ and $5=2-2.5 \mathrm{~m}$. Soil layers with $\mathrm{N}_{\text {inorg }}$ content $<1.8 \mathrm{mg} \mathrm{N} \mathrm{kg}^{-1}$ soil in spring or without roots at harvest were excluded.

\section{Effects of $N$ distribution on root growth}

Three of the four deep-rooted crops in the two experiments, white cabbage, Chinese cabbage and summer squash, responded to more $\mathrm{N}_{\text {inorg }}$ at depths. This was also found in a study of broccoli to $1-\mathrm{m}$ depth, where root intensity and depth were increased by deep placement of $\mathrm{N}_{\text {inorg }}$ compared with shallow placement (Thorup-Kristensen, 1993). Also wheat had greater root density in the 0.3 - to $0.9-\mathrm{m}$ soil layer when nitrate had leached to this depth from the surface soil (Gao et al., 1998). This is in contrast to studies of two Brassicas, kohlrabi and cauliflower, showing effects on yields but not on root density with different vertical distributions of $\mathrm{N}_{\text {inorg }}$ or $\mathrm{N}$ fertilization (Schenk et al., 1991; Rather et al., 2000). The lack of effect could possibly be due to the limited sampling depth of $0.6 \mathrm{~m}$. On the other hand, a study of carrot to 1-m depth showed no effects on root intensity in the deeper parts of the measuring zone and root depth penetration, but in the upper parts decrease in root intensity and less spread of roots into inter-rows were found. This was a response to larger availability of $\mathrm{N}_{\text {inorg }}$ after incorporation of leguminous cover crops compared with smaller availability (Thorup-Kristensen \& Van den Boogaard, 1999). Also spinach showed decreased root density in the upper parts of a measuring zone of 0.6- $\mathrm{m}$ depth and no effects in the deeper parts as a response to shallow placement of soil $\mathrm{N}_{\text {inorg }}$ (large availability) when compared with deep placement (Schenk et al., 1991). For beetroot in the present study, the lack of effect on root growth of $\mathrm{N}_{\text {inorg }}$ distribution contrasts with the results of Christiansen et al. (2006) obtained on the same 
soil: beetroot increased root depth by $0.5 \mathrm{~m}$ and root intensity was more than doubled in the 0.5 - to $2-\mathrm{m}$ soil layer due to deep placement of $\mathrm{N}_{\text {inorg }}$. This response may be explained by the fact that the amount of soil $N_{\text {inorg }}$ was smaller than in the present experiment. However, the biomass production was greater. On the other hand, the closely related sugar beet showed no effect on maximum root depth whereas yield, root growth rate and root density were increased in the 0.3 to $1.8-\mathrm{m}$ soil layer due to $\mathrm{N}$ fertilization (Vamerali et al., 2003). This indicates that the response of beetroot to $\mathrm{N}_{\text {inorg }}$ distribution depends on the $\mathrm{N}$ status of the crop in combination with other factors affecting the resource allocation during growth. For the shallow-rooted leek and potato, the shallow placement of $\mathrm{N}_{\text {inorg }}$ caused a larger $\mathrm{N}$ uptake but root growth was unaffected. Thus, for these shallow-rooted crops the management of cover crops caused differences in $\mathrm{N}_{\text {inorg }}$ availability more than in $\mathrm{N}_{\text {inorg }}$ distribution, as the deep $\mathrm{N}_{\text {inorg }}$ was out of reach of the shallow roots. The results contrast with previous studies of potato where root density and depth were increased due to fertilizer application and subsequent increase in biomass production (Opena \& Porter, 1999; Sharifi et al., 2005). However, in spinach, another shallow-rooted crop, limiting $\mathrm{N}$ supply or deep placement of $\mathrm{N}_{\text {inorg }}$ have both been shown to decrease yield, but increase root density in surface soil layers (Schenk et al., 1991). In general, the effect of $\mathrm{N}_{\text {inorg }}$ distribution on root growth is likely to be closely related to the overall performance and $\mathrm{N}$ nutritional status of the crop. In the present study, the basic $\mathrm{N}$ needs of the crops were met, in the sense that $\mathrm{N}$ availability was adequate to ensure good development and yield of all six crops. Still, the effect of differences in soil $\mathrm{N}_{\text {inorg }}$ distribution on root growth was found to differ between species and experiments with no clear relationship to the $\mathrm{N}$ status of the crop.

\section{Effect of root growth on $N$ uptake}

As noted earlier deep placement of soil $\mathrm{N}_{\text {inorg }}$ increased the root depth penetration by $0.2-$ to $0.4-\mathrm{m}$ at harvest for three of the four deep-rooted crops compared with shallow placement. These increases of root depth also increased the availability of $\mathrm{N}_{\text {inorg }}$ by giving access to a larger volume of soil at depth. A rough calculation, using the concentration of soil $\mathrm{N}_{\text {inorg }}$ found in spring at deep $\mathrm{N}_{\text {inorg }}$ placement, shows that a 0.2- to 0.4-m increase in rooting depth may give access to 9$28 \mathrm{~kg} \mathrm{~N} \mathrm{ha}^{-1}$. Also the changes of root frequency due to $\mathrm{N}_{\text {inorg }}$ distribution may have affected the rate of $\mathrm{N}_{\text {inorg }}$ depletion of the soil. This would influence the amount of $\mathbf{N}_{\text {inorg }}$ left after harvest especially in the deepest and most recently rooted part of the root zones, where time for $\mathrm{N}$ uptake was limited. Large differences between species, were found in the amount of $\mathrm{N}_{\text {inorg }}$ left at harvest in the deep soil layers (Table 1, Figures $1 \mathrm{~b}$ and $2 \mathrm{~b}$ ), and these differences were caused by a combination of the vertical distribution of $\mathrm{N}_{\text {inorg }}$ in spring and the root depth of the vegetable crop. Thus, deep $\mathrm{N}_{\text {inorg }}$ placement followed by a shallow-rooted crop left the largest amount, and shallow $\mathrm{N}_{\text {inorg }}$ placement followed by a deep-rooted crop left the smallest amount. The importance of the crop species for $\mathrm{N}$ cycling in crop rotations in experiment $\mathrm{A}$ is discussed in Thorup-Kristensen (2006a,b). When comparing the effect of species and vertical distribution of soil $\mathrm{N}_{\text {inorg }}$ on root distribution and depth, the differences between species were much larger than the differences caused by the vertical distribution of soil $\mathrm{N}_{\text {inorg }}$, and the species were much more important than the distribution of $\mathrm{N}_{\text {inorg }}$ for the capacity to deplete $\mathrm{N}$ at depth.

The root frequency was calculated to express the ability for soil $\mathrm{N}_{\text {inorg }}$ depletion. The calculation is based on the theory that a few evenly distributed roots are sufficient for uptake of the highly mobile $\mathrm{NO}_{3}{ }^{-}$ion, and that these roots therefore can exhaust soil layers for $\mathrm{NO}_{3}{ }^{-}$over the season (Thorup-Kristensen, 2001). The relationship between root frequencies and decrease in soil $\mathrm{N}_{\text {inorg }}$ was explored in Figure 7. It showed that soil layers with root frequencies below $5 \%$ led to a small decrease in $\mathrm{N}_{\text {inorg}}$. These soil layers were from the deepest part of the root zones that had been recently rooted, and therefore the roots had limited time for $\mathrm{N}_{\text {inorg }}$ uptake. When root frequencies were above $20 \%$, the $\mathrm{N}_{\text {inorg }}$ decrease was at least $40 \%$. Exceptions from this were the deep parts of the root zone of potato and beetroot which indicated a low efficiency in $\mathrm{N}$ depletion by these species. This was probably because the availability of soil $\mathrm{N}_{\text {inorg }}$ exceeded the $\mathrm{N}$ demand. For the other species, there was no further relationship between root frequencies and decreases of $\mathrm{N}_{\text {inorg }}$. Thus, the measure of root frequency was of limited value for expression of the ability for $\mathrm{N}_{\text {inorg }}$ depletion in the present study. However, the lack of relationship may have been caused by the influence of factors other than crop $\mathrm{N}$ uptake on $\mathrm{N}_{\text {inorg }}$ decrease, such as mineralization of soil organic $\mathrm{N}$, leaching and $\mathrm{N}$ application during the experiments.

\section{Conclusion}

Deep placement of soil $\mathrm{N}_{\text {inorg }}$ may increase root depth and density in the deep parts of the rooting zone in some crops compared with shallow placement. The effect may depend on the $\mathrm{N}$ status of the crop. However, the differences in root growth caused by vertical distribution of soil $\mathrm{N}_{\text {inorg }}$ are much smaller than the inherent difference found between species. This means that the capacity of crops to take up $\mathrm{N}$ at depth should be based primarily on the inherent rooting depth of species. Crop rotations should be designed to match root distribution with soil $\mathrm{N}_{\text {inorg }}$ distribution at depth. Effects of vertical distribution of soil $\mathrm{N}_{\text {inorg }}$ on root growth do not need to be taken into account in the design of crop rotations, as these effects are of minor importance for the ability of root systems to take up soil $\mathrm{N}_{\text {inorg }}$ at depth. 


\section{Acknowledgements}

This work was supported by the Danish Research Centre for Organic Farming, and the Danish Institute of Agricultural Sciences. We thank Astrid Bergman, Birthe R. Flyger, Jens Jørgen Jensen, Jens Elkjær, Jens Barfod and Jytte Christiansen for skilful technical assistance, and Erik Jørgensen for statistical support. We thank referees for helpful comments.

\section{References}

Barraclough, P.B., Kuhlmann, H. \& Weir, A.H. 1989. The effects of prolonged drought on nitrogen fertilizer on root and shoot growth and water uptake by winter wheat. Journal of Agronomy and Crop Science, 163, 352-360.

Christiansen, J.S., Thorup-Kristensen, K. \& Kristensen, H.L. 2006. Root development of beetroot, sweet corn and celeriac, and soil $\mathrm{N}$ content after incorporation of green manure. Journal of Horticultural Science and Biotechnology, 81, 831-838.

Di, H.J. \& Cameron, K.C. 2002. Nitrate leaching in temperate agroecosystems: sources, factors and mitigation strategies. Nutrient Cycling in Agroecosystems, 46, 237-256.

Drew, M.C. \& Saker, L.R. 1975. Nutrient supply and the growth of the seminal root system in barley. II. Localized, compensatory increases in lateral root growth and rates of nitrate uptake when nitrate supply is restricted to only part of the root system. Journal of Experimental Botany, 26, 79-90.

EU Water Framework Directive 2000. Directive 2000/60/EC of the European Parliament and of the Council establishing a framework for the community action in the field of work policy.

Forde, B. \& Lorenzo, H. 2001. The nutritional control of root development. Plant and Soil, 232, 51-68.

Gao, S., Pan, W.L. \& Koenig, R.T. 1998. Wheat root growth responses to enhanced ammonium supply. Soil Science Society of America Journal, 62, 1736-1740.

Hodge, A. 2004. The plastic plant: root responses to heterogeneous supplies of nutrients. New Phytologist, 162, 9-24.

Kristensen, H.L. \& Thorup-Kristensen, K. 2004a. Root growth and nitrate uptake of three different catch crops in deep soil layers. Soil Science Society of America Journal, 68, 529-537.

Kristensen, H.L. \& Thorup-Kristensen, K. 2004b. Uptake of ${ }^{15} \mathrm{~N}$ labeled nitrate by root systems of sweet corn, carrot and white cabbage from 0.2 to 2.5 meters depth. Plant and Soil, 265, 93-100.

Opena, G.B. \& Porter, G.A. 1999. Soil management and supplemental irrigation effects on potato. II. Root growth. Agronomy Journal, 91, 426-431.

Parker, C.J., Carr, M.K.V., Jarvis, N.J., Evans, M.T.B. \& Lee, V.H. 1989. Effects of subsoil loosening and irrigation on soil physical properties, root distribtuion and water uptake of potatoes (Solanum tuberosum). Soil and Tillage Research, 13, 267-285.

Rather, K., Schenk, M.K., Everaarts, A.P. \& Vethman, S. 2000. Rooting pattern and nitrogen uptake of three cauliflower (Brassica oleracea var. botrytis) $\mathrm{F}_{1}$-hybrids. Journal of Plant Nutrition and Soil Science, 163, 467-474.

Ruijter, F.J.D., Veen, B.W. \& Van Oijen, M. 1996. A comparison of soil core sampling and minirhizotrons to quantify root development of field-grown potatoes. Plant and Soil, 182, 301-312.

Schenk, M., Heins, B. \& Steingrobe, B. 1991. The significance of root development of spinach and kohlrabi for $\mathrm{N}$ fertilization. Plant and Soil, 135, 197-203.

Sharifi, M., Zebarth, B.J., Hajabbasi, M.A. \& Kalbasi, M. 2005. Dry matter and nitrogen accumulation and root morphological characteristics of two clonal selections of "Russet Norkotah" potato as affected by nitrogen fertilization. Journal of Plant Nutrition, 28, 2243-2253.

Smit, A.L. \& Groenwold, J. 2005. Root characteristics of selected field crops: data from the Wageningen Rhizolab (1990-2002). Plant and Soil, 272, 365-384.

Smit, A.L., Booij, R. \& Van der Werf, A. 1996. The spatial and temporal rooting pattern of brussels sprouts and leeks. Netherlands Journal of Agricultural Science, 44, 57-72.

Stalham, M.A. \& Allen, E.J. 2001. Effect of variety, irrigation regime and planting date on depth, rate, duration and density of root growth in the potato (Solanum tuberosum) crop. Journal of Agricultural Science, Cambridge, 137, 251-270.

Thorup-Kristensen, K. 1993. Root development of nitrogen catch crops and of a succeeding crop of broccoli. Acta Agriculturae Scandinavica Section B, Soil and Plant Science, 43, 58-64.

Thorup-Kristensen, K. 2001. Are differences in root growth of nitrogen catch crops important for their ability to reduce soil nitrate $\mathrm{N}$ content, and how can this be measured? Plant and Soil, 230, 185195.

Thorup-Kristensen, K. 2006a. Effect of deep and shallow root systems on the dynamics of soil inorganic $\mathrm{N}$ during 3-year crop rotations. Plant and Soil, 288, 233-248.

Thorup-Kristensen, K. 2006b. Root growth and nitrogen uptake of carrot, early cabbage, onion and lettuce following a range of green manures. Soil Use and Management, 22, 29-38.

Thorup-Kristensen, K. \& Van den Boogaard, R. 1999. Vertical and horizontal development of the root system of carrots following green manure. Plant and Soil, 212, 145-153.

Thorup-Kristensen, K., Magid, J. \& Jensen, L.S. 2003. Catch crops and green manures as biological tools in nitrogen management in temperate zones. Advances in Agronomy, 79, 227-302.

Vamerali, T., Ganis, A., Bona, S. \& Mosca, G. 2003. Fibrous root turnover and growth in sugar beet (Beta vulgaris var. saccharifera) as affected by nitrogen shortage. Plant and Soil, 255, 169-177.

Weaver, J.E. \& Bruner, W.E. 1927. Root development of vegetables. McGraw-Hill Book Company, New York.

Xie, Z., Wang, Y., Wei, X. \& Zhang, Z. 2006. Impacts of a gravelsand mulch and supplemental drip irrigation on watermelon (Citrullus lanatus (Thunb.) Mats. \& Nakai) root distribution and yield. Soil and Tillage Research, 89, 35-44. 